\title{
RACIAL AND SOCIOECONOMIC SEGREGATION: AN ANALYSIS OF THREE BRAZILIAN METROPOLITAN AREAS
}

\author{
SEGREGAÇÃO RACIAL E SOCIOECONÔMICA: \\ UMA ANÁLISE DE TRÊS ÁREAS METROPOLITANAS \\ BRASILEIRAS
}

\author{
Ernesto Friedrich de Lima Amaral \\ Universidade Federal de Minas Gerais - MG - Brasil
}

\begin{abstract}
Brazil is characterized by racial and socioeconomic segregation. The objective of the research presented here is to analyze socioeconomic and racial segregation in three metropolitan areas (Recife, Belo Horizonte and Porto Alegre). Microdata from the 2000 Brazilian Census was used for this analysis, as well as maps produced for the selected areas by groups of census tracts (áreas de ponderação), using Geographic Information Systems techniques. In general, results indicate that among those areas with a majority of whites, a high proportion of the population holds at least high school degree. Moreover, the nonwhite population lives farther away from the core of the municipality, compared to whites. Finally, whites tend to live in less elevated areas with more public infrastructure and a greater availability of major roads. An improvement to this research could be the inclusion of spatial analysis and statistical models to better understand the relationship between race and socioeconomic indicators.
\end{abstract}

Keywords: Racial segregation; socioeconomic segregation; metropolitan areas; Brazil.

Resumo: O Brasil é caracterizado por segregação racial e socioeconômica. O objetivo desta pesquisa é de analisar a segregação socioeconômica e racial em três áreas metropolitanas (Recife, Belo Horizonte e Porto Alegre). Microdados do Censo Demográfico do Brasil de 2000 foram usados para esta análise, assim como mapas produzidos para os locais selecionados por áreas de ponderação, utilizando técnicas de Sistemas de Informação Geográfica. Em geral, os resultados indicam que em áreas com maioria da população branca, uma alta proporção da população possui pelo menos o ensino médio completo. Além disso, a população não-branca vive longe das áreas centrais do município, em comparação aos brancos. Finalmente, os brancos tendem a viver em áreas menos elevadas, com mais infraestrutura pública e maior disponibilidade de vias públicas principais. Um aperfeiçoamento desta pesquisa poderia ser a inclusão de análise espacial e modelos estatísticos para melhor entender a relação entre indicadores raciais e socioeconômicos.

Palavras-chave: Segregação racial; segregação socioeconômica; áreas metropolitanas; Brasil.

\section{INTRODUCTION}

In Brazil, population segregation by socioeconomic status in large cities is a major problem. Other studies have examined this kind of segregation using income and education data. Several studies on race, racism, and inequality are available, as are comparisons to the United States (Bailey 2009; Daniel 2006; Hasenbalg and Silva 1992; Henriques 2001; Jaccoud and Beghin 2002; Reichmann 1999; Silva 1999; Telles 2004; Telles and Bailey 2002; Telles and Lima 1998). However, there is still a need to deepen the analysis of racial characteristics of the Brazilian population that could contribute to residential segregation. 
Segregation in Brazil has some peculiarities (Telles 2004). On the one hand, residential segregation is moderate, and there is less evidence of racial boundaries in Brazil compared to the U.S. in terms of intermarriage rates and the racial profile of poor neighborhoods. On the other hand, racial segregation still exists, and the disadvantage of nonwhites seems to be explained partly by their spatial isolation from the middle class. The present study aims to analyze the extent to which the Brazilian population is segregated by race and socioeconomic status.

The 2000 Brazilian Census provides a database of socioeconomic and demographic characteristics of the Brazilian population. Moreover, the Brazilian Census Bureau produced maps according to groups of census tracts (áreas de ponderação). An analysis of population segregation by socioeconomic status and race provides an interesting overview of the geographic composition of the country's main municipalities. Previous studies have analyzed race in specific municipalities, such as Recife and Belo Horizonte (Miranda-Ribeiro and Caetano 2003; Miranda-Ribeiro, Caetano and Santos 2004). These municipalities have different race compositions. Recife is located in the Northeast of the country and has a high proportion of black residents. Belo Horizonte has a mixed population, in which white and pardo (multiracial) people are the largest groups. The present study analyzed racial segregation in these metropolitan areas as well as in Porto Alegre. This last urban area is known for its large number of residents of German and Italian descent. This unusual configuration is the result of high levels of international immigration from the 1930s to the 1950s, giving this area one of the highest proportions of whites in the country. This analysis investigated segregation of the poorest population compared to wealthier groups across metropolitan areas with different racial compositions, using data on socioeconomic status as well as race.

\section{PREVIOUS STUDIES}

Scholars have argued that race in Brazil is characterized by plurality, and is not as simple or binary as it may be understood to be in other countries (Freyre 2000; Kamel 2006). One of the main arguments of these studies is that we should not simply divide the population between whites and nonwhites. This would undermine the richness of Brazilian racial characteristics. However, several studies support the idea that the division between upper and lower social classes corresponds to the racial division between whites and nonwhites (Bailey 2009; Daniel 2006; Hasenbalg and Silva 1992; Henriques 2001; Jaccoud and Beghin 2002; Reichmann 1999; Silva 1999; Telles 2004; Telles and Bailey 2002; Telles and Lima 1998). During the 1950s and 1960s, Brazil experienced great economic growth, making it one of the largest industrial economies in the world. During and following these boom years, illiteracy fell, Brazil transitioned from a predominately rural nation to a predominantly urban nation, and its higher education system expanded. Despite these advances, racial disparities increased at the top of the social structure. The expansion of higher education during this period led to the 
growth of a sizable professional middle class, but by disproportionately benefiting whites, it produced a growing racial gap in access to university education. Thus, economic development increased racial inequality in the top part of Brazil's class structure, contrary to the expectations of traditional liberal or modernization perspectives, which argue that industrialization either reduces or does not affect racial inequality. During this period, the federal government invested heavily in higher education while ignoring education at the primary and secondary levels. Further, education targeted at nonwhites was largely ignored. Thus, these studies suggest, the Brazilian socioeconomic structure is largely divided along racial lines: (1) the nonwhite population has lower levels of socioeconomic status compared to whites; and (2) pardos (multiracial) tend to be slightly better off than blacks. However, because white and nonwhite differences are greater than those between pardos and blacks, the former is the primary racial divide in Brazil.

Given this social context, blacks self-identified themselves as pardos in previous censuses. In response, one of the aims of the black movement has been to increase black consciousness. These political dynamics have had some consequences for the quality of data collected by the Brazilian Census Bureau. People use many terms to identify skin-color, but the census simplifies this classification (Carvalho, Wood and Andrade 2004). The 2000 census used the selfidentification method, and has five main classifications of race/color: black (preto), brown/multiracial (pardo), white (branco), yellow/Asian (amarelo), and indigenous (indigena). Because of the self-classification of the black population as pardo in previous years, followed by the rise of black consciousness in recent decades, there was a great deal of migration between these two categories from the 1970 to the 2000 census. A strategy to deal with this problem was to replace the distinct color categories of preto and pardo with the single racial category of negro (Carvalho, Wood and Andrade 2003, 2004; Wood and Carvalho 1994). The net result has been a race relation's shift in Brazil, towards a greater emphasis on the white vs. nonwhite dichotomy. The amarelo and indigena categories are not usually analyzed in these studies because they represent less than $1 \%$ of the national population. Despite the new literature on race, little or no work has examined residential segregation by race in Brazil.

\section{DATA AND METHODS}

Microdata from the 2000 Brazilian Census was used for this analysis. The Census Bureau collected microdata from $10 \%$ or $20 \%$ of households, depending on the size of the municipality. This census is available in a database with socioeconomic and demographic characteristics of the population. A spatial analysis was completed with the aid of maps produced by the Census Bureau (Brazilian Institute of Geography and Statistics - IBGE), which render the national territory by groups of census tracts (áreas de ponderação). Since those maps only have a polygon layer with group of census tracts, other maps were used to provide data on roads and elevation. The Census Bureau also compiled these layers called 
the "Integrated Cartographic Database of Brazil" (Base Cartográfica Integrada do Brasil ao Milionésimo Digita). The census microdata and maps were used to analyze racial and socioeconomic segregation using Geographic Information Systems (GIS) techniques.

The Brazilian census has five categories of race, as was explained above: black (preto), brown/multiracial (pardo), white (branco), yellow/Asian (amarelo), and indigenous (indigena). Based on the findings of previous studies, we dichotomized these racial characterizations (Wood and Carvalho 1994; Carvalho, Wood and Andrade 2003; Carvalho, Wood and Andrade 2004; Telles 2004). Whites were compared to a combined category including both pardos and pretos, known in Portuguese as negros. Members of this group are also referred to in this study as nonwhites. Because amarelos and indigenas represent a small percentage in the population under consideration, they are not analyzed in the present study.

The three selected urban areas are Recife, Belo Horizonte and Porto Alegre (Figure 1). These municipalities are the state capitals of Pernambuco (in the Northeast region), Minas Gerais (in the Southeast region), and Rio Grande do Sul (in the South region). Because current analysis of the Brazilian territory shows that lower classes have been moving to surrounding municipalities around primary municipalities, this study investigated segregation patterns in the micro-regions of the selected urban areas. Micro-regions are groups of municipalities defined by $I B G E$, and are similar to counties in the United States context.

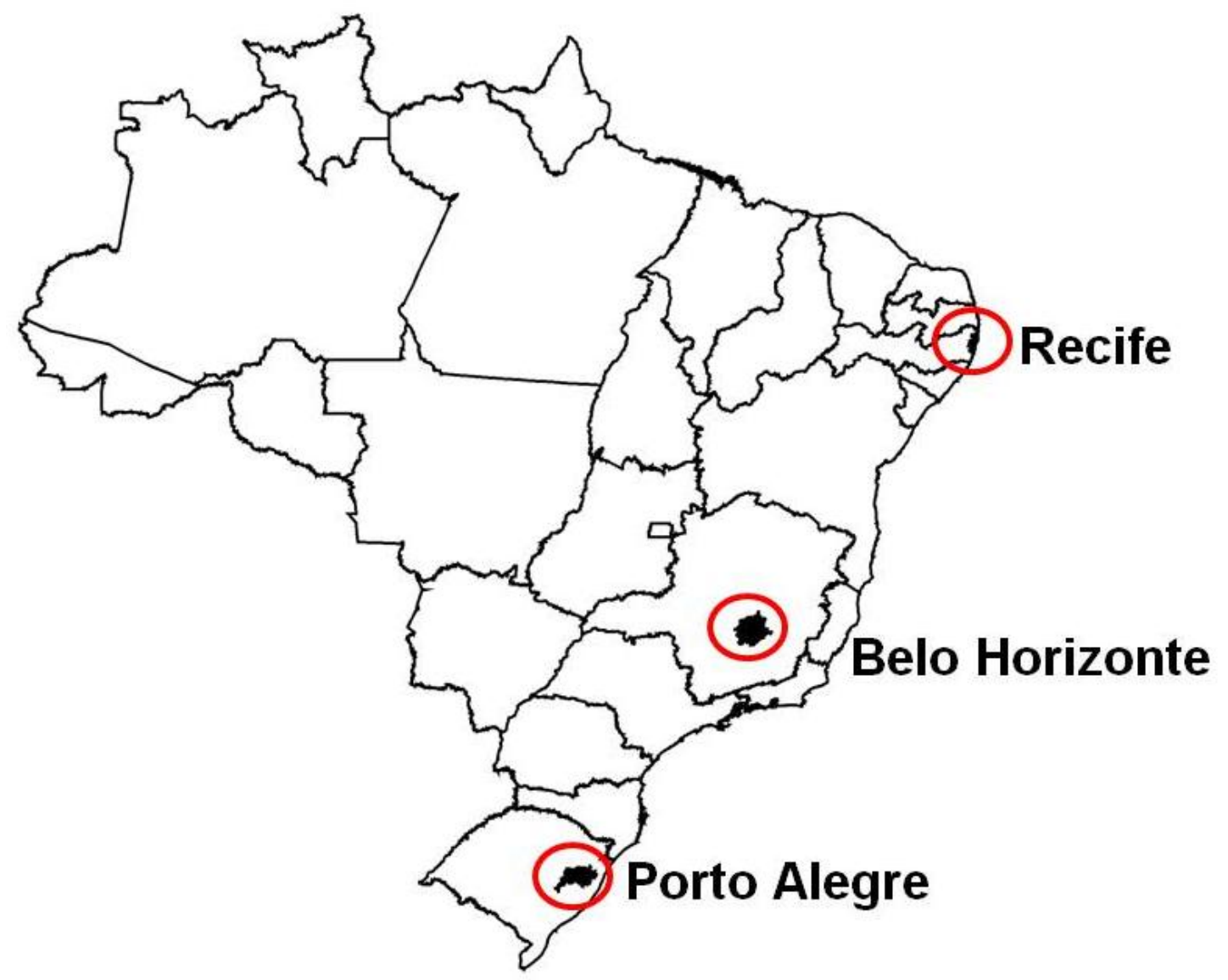

Figure 1. Selected Brazilian metropolitan areas, 2000.

Source: 2000 Brazilian Demographic Census. 
Information about the populations of the three selected Brazilian metropolitan areas was extracted from the 2000 demographic census (Table 1). The micro-region of Recife includes eight municipalities. The municipality of Recife itself has 1,422,905 inhabitants. The micro-region of Recife has 2,991,948 inhabitants and 117 groups of census tracts defined by IBGE. The micro-region of Belo Horizonte includes 24 municipalities. The municipality of Belo Horizonte has 2,238,526 inhabitants, and the micro-region of Belo Horizonte has 4,259,163 inhabitants. However, only 13 of those 24 municipalities have maps provided by IBGE, with a total of 126 census tract groups. The micro-region of Porto Alegre has 21 municipalities. The municipality of Porto Alegre has 1,360,590 inhabitants, and its micro-region has 3,425,044 inhabitants. Only 15 of those 21 municipalities have maps provided by the Brazilian census bureau, with 147 groups of census tracts in total. We analyzed only those municipalities with available spatial data.

Table 1. Population characteristics of the selected Brazilian metropolitan areas, 2000.

\begin{tabular}{c|ccc}
\hline Variables & Recife & $\begin{array}{c}\text { Belo } \\
\text { Horizonte }\end{array}$ & $\begin{array}{c}\text { Porto } \\
\text { Alegre }\end{array}$ \\
\hline $\begin{array}{c}\text { Total } \\
\text { population } \\
\text { with maps }\end{array}$ & $\begin{array}{c}2,991,948 \\
(100.0 \%)\end{array}$ & $\begin{array}{c}4,052,705 \\
(95.2 \%)\end{array}$ & $\begin{array}{c}3,348,234 \\
(97.8 \%)\end{array}$ \\
$\begin{array}{c}\text { Percentage } \\
\text { in central } \\
\text { municipality } \\
\text { Number of } \\
\text { municipalities } \\
\text { with maps } \\
\begin{array}{c}\text { Number of } \\
\text { groups of census tracts } \\
\text { (áreas de ponderação) }\end{array}\end{array}$ & 47.6 & 55.2 & 40.6 \\
\hline
\end{tabular}

Source: 2000 Brazilian Demographic Census.

The map categories illustrate the percentage of whites in census tract groups. These categories were defined in order to allow comparisons among the maps of Recife, Belo Horizonte and Porto Alegre. The following percentage categories were utilized: $25.1-35.0 ; 35.1-45.0 ; 45.1-55.0 ; 55.1-65.0 ; 65.1-75.0$; 75.1-85.0; 85.1-95.0; and 95.1-100.0. However, the metropolitan area of Recife does not have census tract groups with more than $85.0 \%$ of the population being white (top two categories). The metropolitan region of Belo Horizonte does not have census tract groups with more than $95.0 \%$ of the population being white (top category). Finally, the metropolitan region of Porto Alegre does not have census tract groups with less than $65.1 \%$ of the population being white (bottom four categories). The proportion of whites was calculated as a percentage of the total population within each census tract group, while ignoring amarelos and 
indigenas residents. Information on years of schooling was also taken from the 2000 Brazilian Census. This variable is not presented on maps but was analyzed in conjunction with the proportion of whites by census tract group. This variable is a more useful measure of socioeconomic status than individual income (Telles 2004; Bailey 2009). The education variable is often used as a proxy for socioeconomic status. The income variable tends to be biased in the census microdata.

\section{RESULTS}

Figure 2 presents the differences in racial composition among Recife, Belo Horizonte and Porto Alegre showing each metropolitan area's population by race in 2000 . While $55.7 \%$ of Recife's population self-identified as preto/pardo, $51.1 \%$ of Belo Horizonte residents identified as preto/pardo, and only $13.9 \%$ of the Porto Alegre population identified as preto/pardo. The selection of these three metropolitan areas was intentional. These three areas represent different regions of the country with diverse race compositions. Figure 3 illustrates the distribution of education in the selected metropolitan areas. It is interesting to note that, in all three areas, approximately $70 \%$ of the population has less than a high school degree, and less than $30 \%$ of the population has at least some high school. Thus, these data point to different racial compositions in the three metropolitan areas, but also to similar educational patterns across Recife, Belo Horizonte and Porto Alegre.

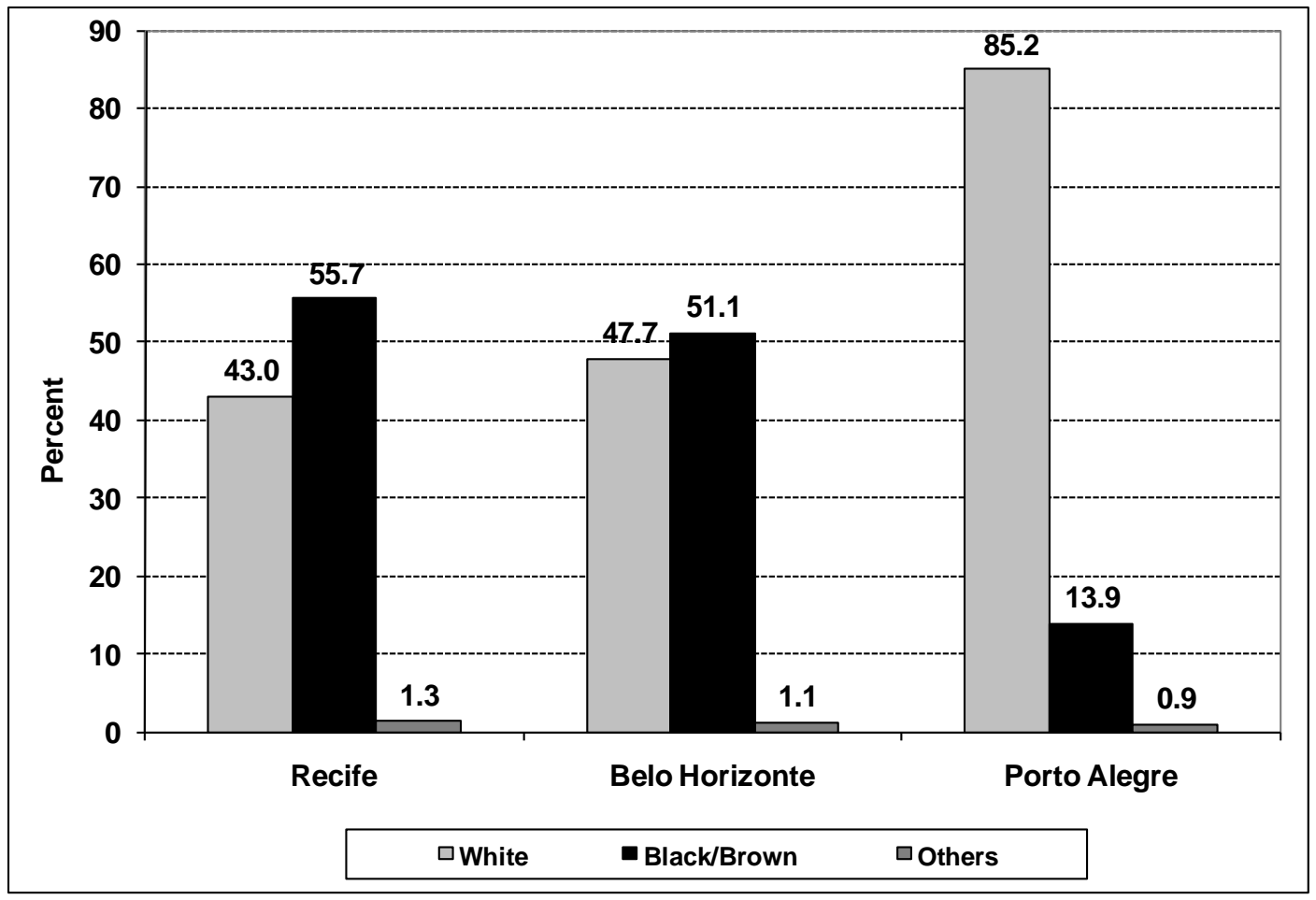

Figure 2. Percentage of the population of the selected Brazilian metropolitan areas by race, 2000.

Source: 2000 Brazilian Demographic Census. 


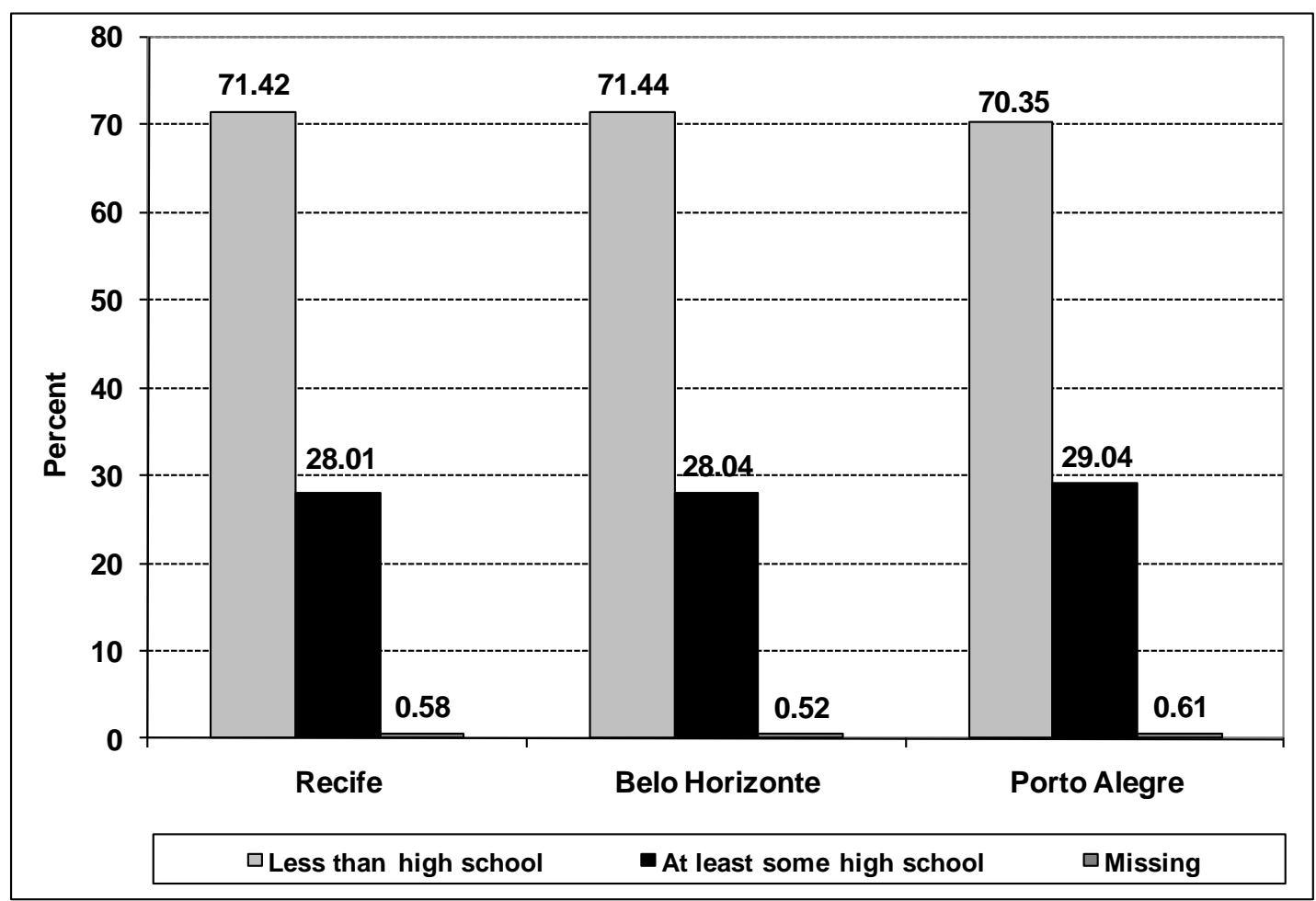

Figure 3. Percentage of the population of the selected Brazilian metropolitan areas by education, 2000.

Source: 2000 Brazilian Demographic Census.

The index of dissimilarity is one technique for measuring the segregation of white and nonwhite in the group of census tracts of each metropolitan area. This measure uses a range from zero to one-unit; the higher the number, the more segregated the two groups are. The index was calculated using the race variable (white vs. preto/pardo) and the education variable (less than high school vs. at least some high school) by census tract group in Recife, Belo Horizonte and Porto Alegre. The results (Table 2) indicate that there is greater segregation by education than by race for all metropolitan areas. However, the indexes for race are still high. For instance, $27 \%$ of the Porto Alegre population would have to move to different locations in order to create an equal distribution of whites and nonwhites in all census tract groups. 
Table 2. Index of dissimilarity of the selected Brazilian metropolitan areas by race and education, 2000.

\begin{tabular}{c|ccc}
\hline $\begin{array}{c}\text { Index of } \\
\text { dissimilarity }\end{array}$ & Recife & $\begin{array}{c}\text { Belo } \\
\text { Horizonte }\end{array}$ & $\begin{array}{c}\text { Porto } \\
\text { Alegre }\end{array}$ \\
\hline $\begin{array}{c}\text { Segregation } \\
\text { by race }\end{array}$ & 0.17 & 0.24 & 0.27 \\
$\begin{array}{c}\text { Segregation } \\
\text { by education }\end{array}$ & 0.27 & 0.31 & 0.32 \\
\hline
\end{tabular}

Source: 2000 Brazilian Demographic Census.

The spatial distribution of the population by race and education elucidates segregation patterns in the selected metropolitan areas. Data for the micro-region of Recife is shown in Figure 4. This map indicates that groups of census tracts with majority white populations are located within 10 kilometers from the coast. Thus, areas with majority white populations are concentrated in the core of the municipality, within the highway limits. Those groups of census tracts with a majority preto/pardo population are concentrated in the periphery of the metropolitan areas, outside the highway limits. This provides some evidence that the wealthiest population is living close to the coast and within areas with better infrastructure; the wealthiest population seems to live within the municipality of Recife itself, rather than in other municipalities around it. The education variable was analyzed with race information but is not shown in the map. Among those groups of census tracts with a majority white population, almost $80 \%$ have population majorities with at least a high school degree. Among the group of census tracts with a majority of preto/pardo population, none have majority populations with at least a high school degree. This is strong support for the findings of Telles (2004), who emphasizes large socioeconomic and educational differentials between whites and negros. 


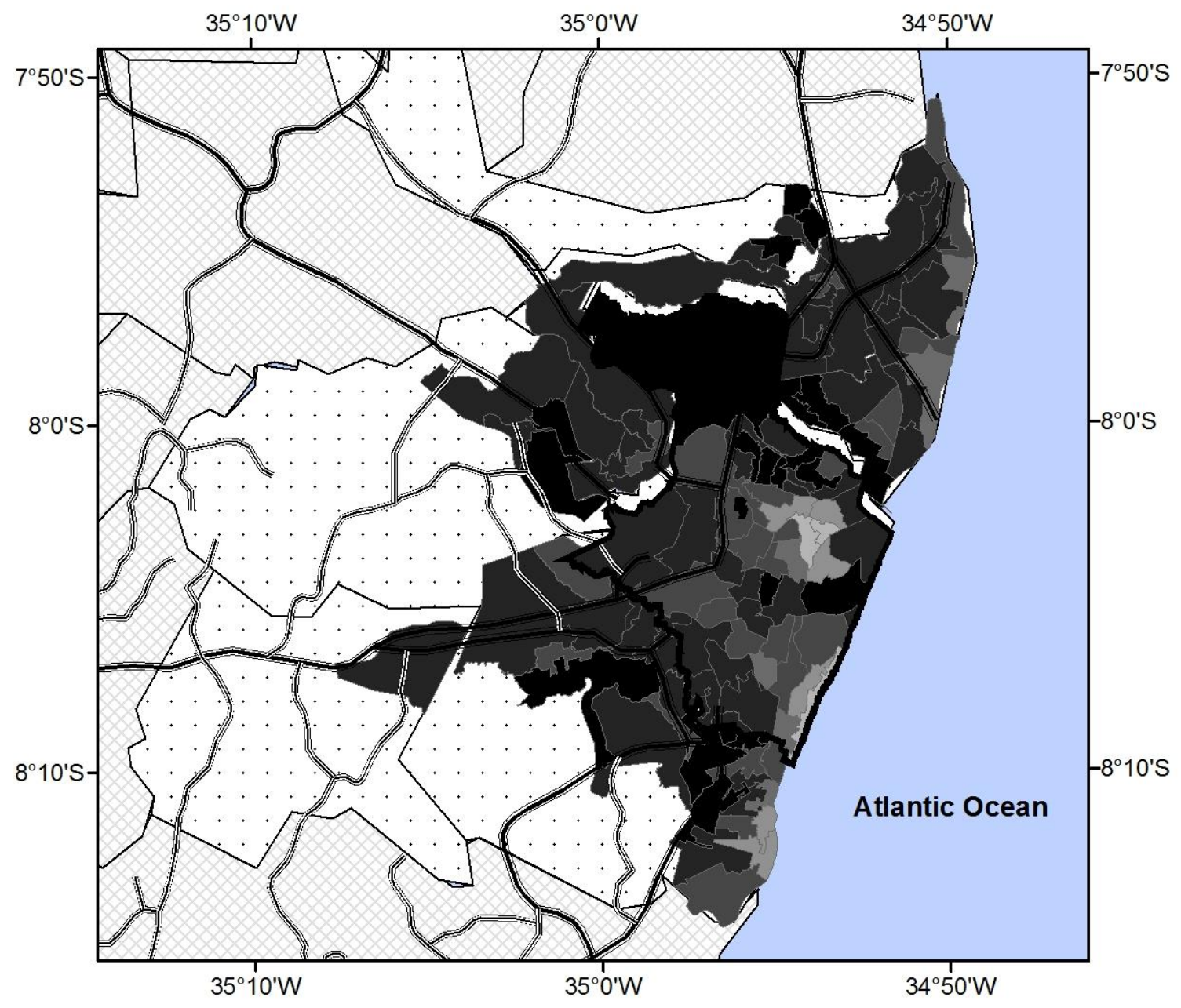

\section{LEGEND}
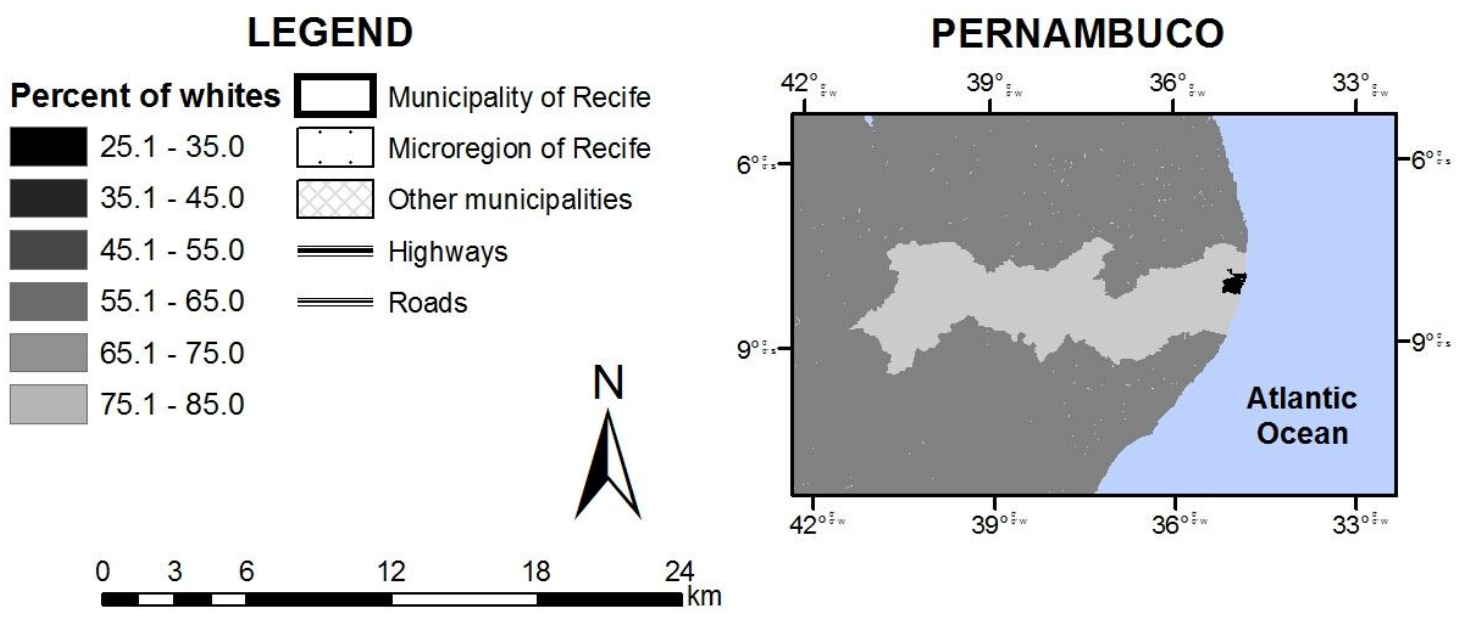

Figure 4. Percent of whites within each census tract group (área de ponderação) in the metropolitan area of Recife, 2000.

Note: Since the metropolitan area of Recife does not have census tract groups with more than $85.0 \%$ of the population being white, the top two categories are not included in the legend of this map.

Source: 2000 Brazilian Demographic Census. 
The map of the Belo Horizonte micro-region can be found in Figure 5 . Groups of census tracts with white majorities are concentrated in the municipality of Belo Horizonte. Areas with preto/pardo majorities are located in municipalities around Belo Horizonte, mainly along the northern border. Among the groups of census tracts with preto/ pardo majorities, almost $71 \%$ of areas have $16 \%$ or less of the population with at least a high school education. In addition, groups of census tracts with larger white populations are located in areas with low elevation (not shown in the map). Areas with larger preto/pardo populations are in locations with at least 800 meters of elevation. In some cases, these groups of census tracts are located in areas with as much as 1,200 meters of elevation. This means that these populations tend to live on hills and mountains around the main municipality, where the public infrastructure is worse than in the core of the urban area. 


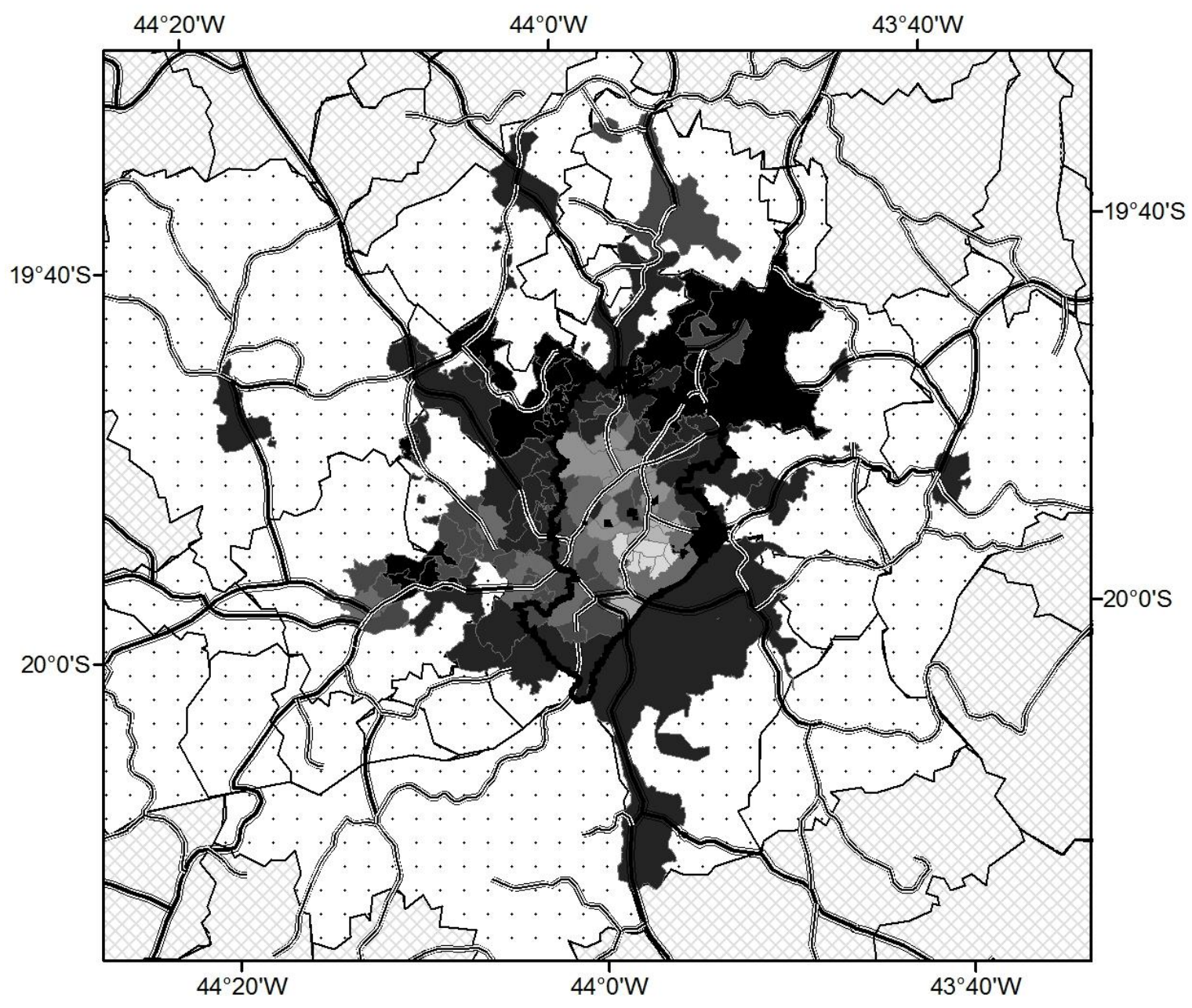

\section{LEGEND}

MINAS GERAIS

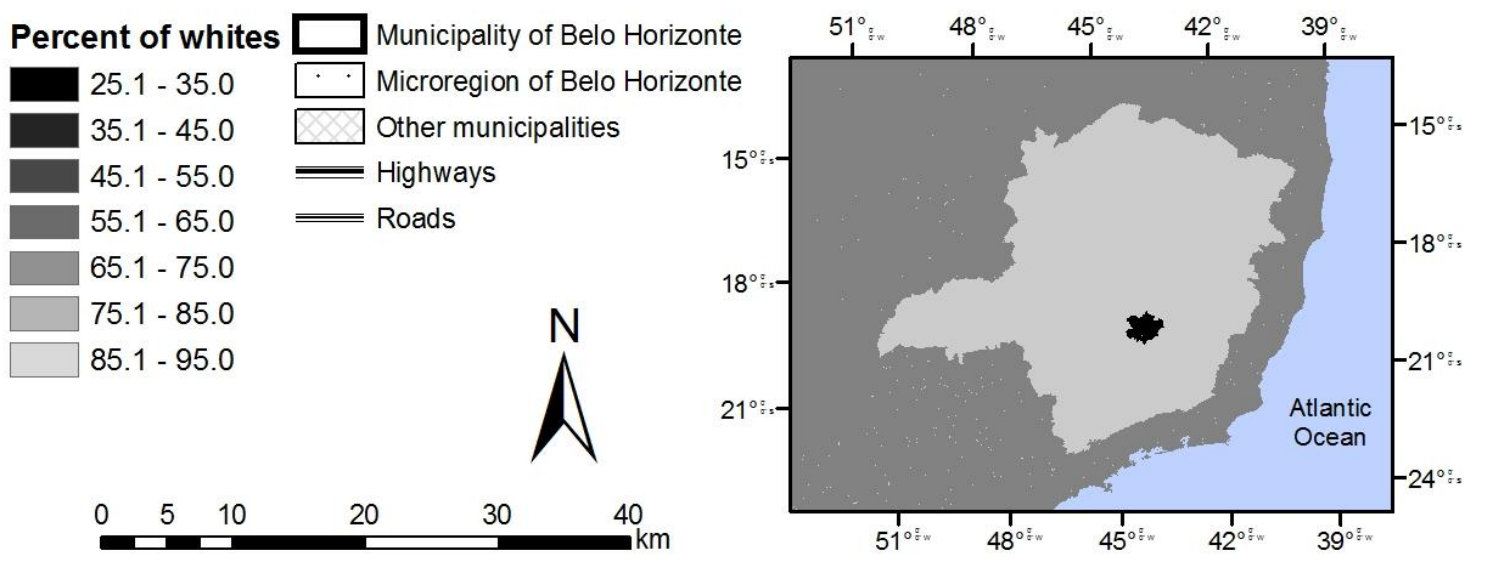

Figure 5. Percent of whites within each census tract group (área de ponderação) in the metropolitan area of Belo Horizonte, 2000.

Note: Since the metropolitan region of Belo Horizonte does not have census tract groups with more than $95.0 \%$ of the population being white, the top category is not included in the legend of this map.

Source: 2000 Brazilian Demographic Census. 
Figure 6 illustrates the racial distribution of the Porto Alegre micro-region. First of all, it is necessary to point out that the percentage of white residents in the Porto Alegre area is much higher than in the two previous urban areas. The groups of census tracts with lower percentages of whites are still between $65.1 \%$ and $75.0 \%$ white. This relatively high proportion is the result of historical immigration patterns in the 1930s and 1940s, when migrants arrived in the area from Germany and Italy. This different pattern is important for this research because it allows us to analyze racial segregation in metropolitan areas with diverse racial compositions. Even in Porto Alegre, an urban area with higher percent of white population comparing to other areas in Brazil, the groups of census tracts with lower percentages of whites have worse socioeconomic characteristics compared to those with higher percentages of white residents. Another interesting characteristic of Porto Alegre is that the main highways connect the census tract groups with the highest proportions of white population. This is the case of the highway that goes from the south of the micro-region to the north part of this area. The most elevated areas in the south of the micro-region (at least 100 meters) have a higher proportion of preto/ pardo residents (elevation is not shown in the map). Census tract groups with lower proportions of whites are concentrated in the eastern part of the area. Almost $60 \%$ of areas with the highest proportions of white population also have a majority of their populations holding at least high school degrees. In contrast, in areas with higher proportions of preto/ pardo population, only $1.4 \%$ have a majority of residents holding a high school degree or higher. 


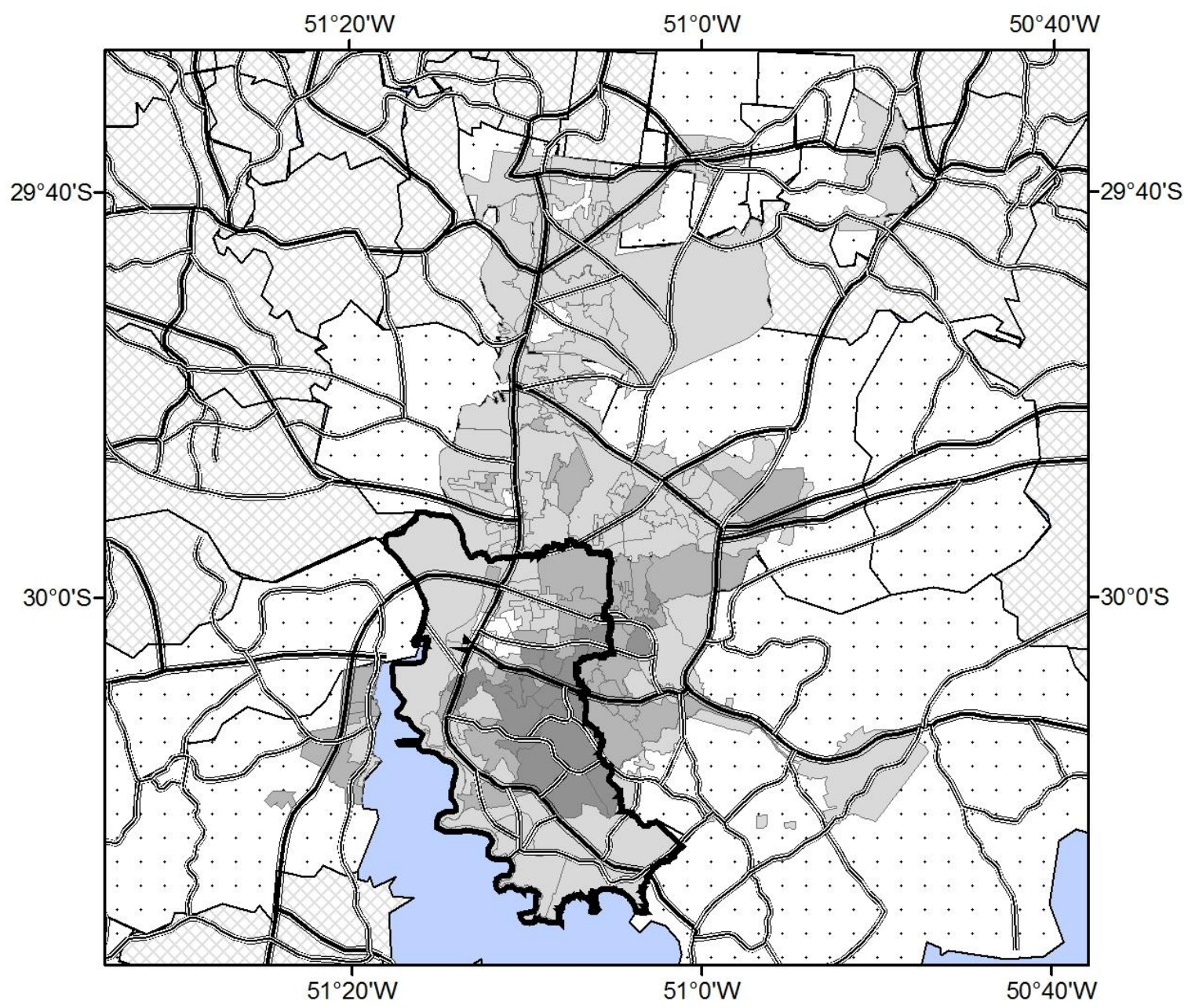

LEGEND

RIO GRANDE DO SUL

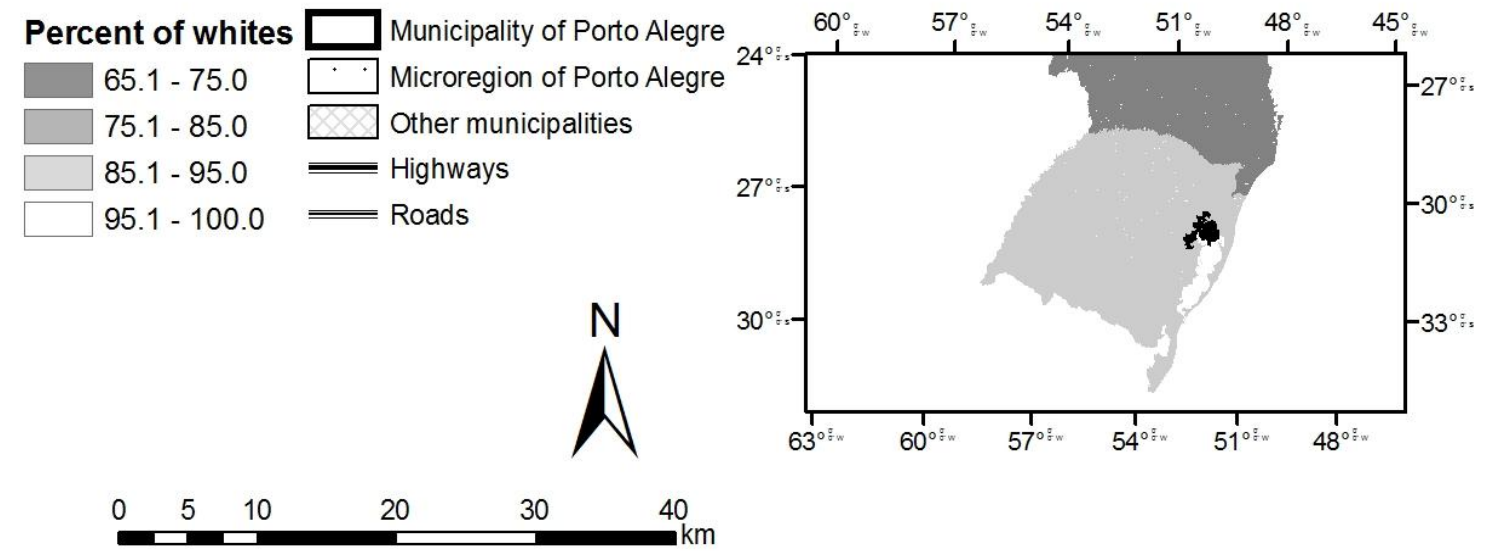

Figure 6. Percent of whites within each census tract group (área de ponderação) in the metropolitan area of Porto Alegre, 2000.

Note: Since the metropolitan region of Porto Alegre does not have census tract groups with less than $65.1 \%$ of the population being white, the bottom four categories are not included in the legend of this map.

Source: 2000 Brazilian Demographic Census. 


\section{FINAL CONSIDERATIONS}

This analysis of racial segregation in three metropolitan areas was conducted with attention to education levels, neighborhood elevation and access to main roads. In general, the spatial analysis for the micro-regions of Recife, Belo Horizonte and Porto Alegre indicated significant spatial segregation in those urban areas by both race and socioeconomic status. Education was used as a proxy for socioeconomic status. Areas with lower elevation are more likely to have higher proportions of whites. More elevated areas, which tend to have worse public infrastructures, have higher proportions of nonwhites. Main roads tend to link white neighborhoods, as in the case of Porto Alegre, and tend to separate white from nonwhite areas, as in the case of Recife. Further research using spatial regression models to better understand the relationship between race and socioeconomic status in these communities is already underway.

\section{REFERENCES}

BAILEY, S. R. Legacies of Race: Identities, Attitudes, and Politics in Brazil. Stanford: Stanford University Press, 2009.

CARVALHO, J. A. M.; WOOD, C. H.; ANDRADE, F. C. D. Notas acerca das categorias de cor dos censos e sobre a classificação subjetiva de cor no Brasil: 1980/90. Revista Brasileira de Estudos de População, v. 20, n. 1, p. 29-42, 2003.

CARVALHO, J. A. M.; WOOD, C. H.; ANDRADE, F. C. D. Estimating the stability of census-based racial/ethnic classifications: the case of Brazil. Population Studies, v. 58, n. 3, p. 331-343, 2004.

DANIEL, G. R. Race and Multiraciality in Brazil and the United States: Converging Paths? University Park: The Pennsylvania State University Press, 2006.

FREYRE, G. Casa Grande e Senzala: Formação da Família Brasileira sob o Regime de Economia Patriarcal. 41. ed. Rio de Janeiro: Record, 2000.

HASENBALG, C. A.; SILVA, N. V. Relações Raciais no Brasil Contemporâneo. Rio de Janeiro: Rio Fundo Ed, 1992.

HENRIQUES, R. Desigualdade racial no Brasil: evolução das condições de vida na década de 90. IPEA - Texto para Discussão, n. 807, p. 1-49, 2001.

JACCOUD, L.; BEGHIN, N. Desigualdades Raciais no Brasil: um Balanço da Intervenção Governamental. Brasília: IPEA, 2002.

KAMEL, A. Não Somos Racistas: uma Reação aos que Querem nos Transformar numa Nação Bicolor. Rio de Janeiro: Nova Fronteira, 2006. 
MIRANDA-RIBEIRO, P.; CAETANO, A. J. O programa SRSR. Revista Brasileira de Estudos de População, v. 20, n. 2, p. 303-305, 2003.

MIRANDA-RIBEIRO, P.; CAETANO, A. J.; SANTOS, T. F. Saúde Reprodutiva, Sexualidade e Raça/Cor: Relatório Descritivo. Belo Horizonte: CEDEPLAR/UFMG, 2004.

REICHMANN, R. (Org.). Race in Contemporary Brazil: From Indifference to Inequality. University Park: The Pennsylvania State University Press, 1999.

SILVA, N. V. Uma nota sobre "raça social" no Brasil. In: Hasenbalg, C.; SILVA, N. V.; LIMA, M. (Org.) Cor e Estratificação Social. Rio de Janeiro: Contra Capa Livraria, 1999, p. 107-125.

TELLES, E. E. Race in Another America. Princeton: Princeton University Press, 2004.

TELLES, E. E.; BAILEY, S. R. Políticas contra o racismo e opinião pública: comparações entre Brasil e os Estados Unidos. Opinião Pública, v. 8, n. 1, p. 3039, 2002.

TELLES, E. E.; LIMA, N. Does it matter who answers the race question? Racial classification and income inequality in Brazil. Demography, v. 35, n. 4, p. 465474, 1998.

WOOD, C. H.; CARVALHO, J. A. M. Categorias do censo e classificação subjetiva de cor no Brasil. Revista Brasileira de Estudos Populacionais, v. 11, n. 1, p. 3-17, 1994.

\section{ACKNOWLEDGEMENTS}

I am grateful to the reviewers of this journal, for their valuable suggestions and comments. I would also like to thank Adriane Reams for editing this paper.

Submetido em 17/04/2012.

Aprovado em 05/04/2013.

Sobre o autor

Ernesto Friedrich de Lima Amaral

$\mathrm{PhD}$ in Sociology/Demography from the University of Texas at Austin. Assistant Professor at the Universidade Federal de Minas Gerais (UFMG).

Address: Avenida Antônio Carlos, 6627, FAFICH 4111, Pampulha. CEP. 31270-901 - Belo Horizonte, MG - Brasil.

E-mail: eflamaral@gmail.com 